\title{
Efficacy of bosentan in the treatment of pulmonary hypertension; a prospective study focusing on safety and efficacy in patients with COPD
}

\begin{abstract}
Objective: The aim of this study was to investigate the efficacy of Bosentan, an endothelin antagonist of endothelin receptors, in patients with mild to moderate pulmonary hypertension secondary to chronic obstructive pulmonary disease (COPD) and to prove whether Bosentan is able to improve clinical, functional and hemodynamic functions in patients affected by COPD and pulmonary hypertension.

Material and methods: This was a prospective investigator initiated trial conducted at multi center from May 2016 till August 2017. After ethics committee approval, 40 Patients meeting the eligibility criteria were included in the study. Patients of both gender with chronic obstructive pulmonary disease and mean pulmonary arterial pressure of $>25 \mathrm{~mm} \mathrm{Hg}$ were included in the study. Patients with group 1 pulmonary arterial hypertension, structural lung disease, past history of tuberculosis and having any contraindication to Bosentan monohydrate were excluded from the study. Total 40 patients were prescribed with $62.5 \mathrm{mg}$ of Bosentan monohydrate therapy twice daily for 4 weeks as per physician discretion. There were 3 study visits performed: at baseline, at $4^{\text {th }}$ week and at $12^{\text {th }}$ week. After recording of the demographic variables, primary and secondary outcomes were evaluated on each visit. The mean pulmonary arterial pressure was assessed by trans-thoracic Echocardiography using the gradient method. Data analysis was performed using SPSS version 20.0 Paired $\mathrm{t}$ - test, and fisher exact test to assess the difference. The $\mathrm{p}$-value of $<0.05$ was considered as significant.
\end{abstract}

Results: The mean age of the study participants was $59.31 \pm 9.23$ years; mean height was $162.29 \pm 8.67 \mathrm{~cm}$ where as mean weight was $62.94 \pm 18.01 \mathrm{~kg}$, with male to female ratio of $2: 1$. During observation of the patients before and after the treatment for 12 week duration, the most significant finding was improvement in shortness of breath at rest $(p=0.031)$ and physical activity $(\mathrm{p}<0.001)$. The improvements were also observed in performing daily $(\mathrm{p}=0.025)$ and social activities $(\mathrm{p}=0.046)$. The MMRC dyspnea scale grades of the patients had significant difference before and after the treatment $(\mathrm{p}<0.01)$.The mean pulmonary arterial pressure was performed in 28 patients. It was $52.26 \pm 11.7 \mathrm{mmHg}$ before treatment and after treatment it was $44.56 \pm 11.52$ ( $\mathrm{p}$ value $=0.004$ ). The six minute walk test was performed in 15 patients. It was $164 \pm 94.79$ meters before therapy and $223.93 \pm 138.24$ meters after treatment. ( $\mathrm{p}$ value $=0.01$ ). Only two cases were reported with side effects of dyspnea and oral candidiasis.

Conclusions: Even though it was an uncontrolled prospective study, Bosentan appeared to be effective in the treatment of dyspnea, limitation in physical activities, pulmonary hypertension and inability to walk due to shortness of breath in patients of chronic obstructive pulmonary disease suffering from pulmonary hypertension.

Keywords: bosentan monohydrate, pulmonary arterial pressure, efficacy
Volume 5 Issue 2 - 2018

\author{
Nasir Hussain,' Faisal Faiyaz Zuberi, ${ }^{2}$ Kausar \\ Rehana, ${ }^{3}$ Saadia Ashraf, ${ }^{4}$ Anjum Naveed \\ Jamal, ${ }^{5}$ Shafi Khawar, ${ }^{6}$ Talat Mehmood, ${ }^{7}$ \\ Neeta Maheshwary ${ }^{8}$ \\ 'Consultant Pulmonologist, Private practice at National Medical \\ Center, Pakistan \\ ${ }^{2}$ Associate Professor, Dow University of health sciences, \\ Pakistan \\ 3Professor, PIMS; Islamabad, Pakistan \\ ${ }^{4}$ Associate Professor, KTH; Peshawar, Pakistan \\ ${ }^{5}$ Associate Professor, MIC; Multan, Pakistan \\ ${ }^{6}$ Consultant, GMMC; Sukkur, Pakistan \\ ${ }^{7}$ Consultant, Allergy Clinic; Faislabad, Pakistan \\ ${ }^{8}$ Sr. Manager Medical Affairs \& Clinical Research, Hilton Pharma \\ PVT Ltd. Pakistan
}

Correspondence: Neeta Maheshwary MBBS, Sr. Manager Medica Affairs \& Clinical Research, Hilton Pharma PVT Ltd, Progressive Plaza, Beaumont Road, Pakistan, Tel (02 I) I I I-I23000/0092-3228247773,Email drneeta@hiltonpharma.com

Received: March 26, 2018 | Published: April 23, 2018

\section{Introduction}

The chronic obstructive pulmonary disease (COPD) usually results in pulmonary hypertension $(\mathrm{PH})$ and about $40 \%$ of patients with COPD suffer from pulmonary hypertension during the course of their illness, that results in worsened prognosis of the disease. ${ }^{1,2}$ Some studies have defined $\mathrm{PH}$ as a PAP $>25 \mathrm{~mm} \mathrm{Hg}{ }^{3,4}$ Most patients of COPD develop mild to moderate $\mathrm{PH}$ with only slight degree of elevation in PAP. ${ }^{5} \mathrm{PH}$ is an essential prognostic factor in determining the course of illness in a patient suffering from COPD. ${ }^{5,6}$ In fact, some studies suggest that the severity of elevated levels of PAP is a more reliable predictor of prognosis in COPD patients in comparison to FEV1, hypoxemia or hypercapnia. ${ }^{6,7}$ It has been found that COPD patients who have PAP of $>18 \mathrm{~mm} \mathrm{Hg}$, are more often admitted to hospital due to exacerbations of their condition as compared to those having a mean PAP of $<18 \mathrm{~mm}$ Hg. ${ }^{5}$ The exacerbations of COPD in patients with $\mathrm{PH}$ are responsible for an increase in mortality and morbidity. ${ }^{8}$

$\mathrm{PH}$ worsens the condition of patients with severe COPD especially after hypoxemic respiratory insufficiency. Long term therapy with oxygen is considered to be the choice of treatment as there is lack of availability of an approved drug for COPD-induced PH. The goal of the oxygen therapy is to reverse hypoxemic vasospasm which is caused by acute hypoxemia that results in worsening of $\mathrm{PH}$ in 
patients with COPD. ${ }^{9,10}$ When this state of hypoxemia becomes long standing, structural changes in the pulmonary arterioles take place. These changes are characterized by the thickening of the pulmonary arterioles in the tunica media, intimal multiplying and tendency for native thrombosis. ${ }^{8,10}$ A study showed that due to these structural changes in pulmonary arterioles caused by long standing hypoxemia in COPD patients, pulmonary hypertension can become a critical problem that are refractory to oxygen therapy and vasodilators. ${ }^{11}$ It is predicted that even though $\mathrm{PH}$ is caused owing to the damage of capillary architecture in patients with COPD, however, increased levels of PAP are not related with oxygen therapy in patients with severe COPD. However, it is related with raised pulmonary wedge pressure revealing left diastolic malfunction in spite of conservation of systolic ventricular function. ${ }^{12} \mathrm{PH}$ induced by aberrant vascular remodeling in cigarette smokers has been reported and a association with minor airway disease and other COPD conditions such as emphysema established..$^{13}$ Nevertheless, it remains unclear whether severe $\mathrm{PH}$ in the above quoted conditions is secondary to primary idiopathic pulmonary arterial hypertension $(\mathrm{PAH})$ or COPD. ${ }^{6}$

As cited above, there is no appropriate drug existing for COPDinduced $\mathrm{PH}$, therefore the first line treatment in patients with $\mathrm{PH}$ occurring secondary to COPD and hypoxemia, is to treat the underlying disease and administer oxygen therapy. ${ }^{14,15}$ Vasodilators have been found to be beneficial only in patients with severe PH secondary to COPD, with only mild to moderate ventilatory impairment and dysfunction. ${ }^{7}$ Nevertheless, stated beneficial properties of the administered vasoactive medications are unreliable and dependable statistics validating this declaration are absent., ${ }^{4,16}$

It has been suggested to treat the hypoxemia secondary to COPD, by keeping a state of balance within the endothelial system that may delay or even prevent the vascular remodeling. ${ }^{1}$ Endothelin is regarded as an endothelial paracrine intermediary that is accountable for pulmonary arterial hypertension. The levels of endothelin in patients with COPD are elevated specifically during an exacerbation. ${ }^{18,19}$ Thus, the main factor that is responsible for vascular remodeling might be endothelin, since this peptide induces the spread of myocytes in the tunica adventitia of the pulmonary arterioles and also causes fibrosis and spread of endothelial cells in the tunica adventitia. ${ }^{19,20}$ The purpose of this study was to investigate the efficiency of Bosentan, an endothelin receptors antagonist, in patients with mild to moderate pulmonary hypertension $(\mathrm{PH})$ secondary to chronic obstructive pulmonary disease (COPD) and to prove whether Bosentan is capable to recover hemodynamic and clinical features.

\section{Methodology}

This was a prospective investigator initiated trial conducted at multi center from May 2016 till August 2017. A total of 40 patients meeting the eligibility criteria were incorporated in the study using convenient sampling technique. Patients of both gender with chronic obstructive pulmonary disease and pulmonary arterial pressure of $>25 \mathrm{~mm} \mathrm{Hg}$ were included in the study. Patients with group 1 pulmonary arterial hypertension, structural lung disease, past history of tuberculosis and having contradiction to any of the products of Bosentan monohydrate were excluded from the study.

Total 40 patients were prescribed with $62.5 \mathrm{mg}$ of Bosentan monohydrate therapy twice daily for 4 weeks as per physician discretion. There were 3 study visits performed: at baseline, at $4^{\text {th }}$ week and at $12^{\text {th }}$ week. After recording of the demographic variables, primary and secondary outcome were evaluated on each visit. The primary outcomes comprised of change from base line to $12^{\text {th }}$ week in exercise capacity, indicated by the distance a patient could walk in six minutes (6min Walk Test), dyspnea score and clinical COPD questionnaire and modified medical research council (MMRC) dyspnea scale. The MMRC scale was classified through breathlessness on strenuous exercise, short of breath when hurrying or walking a slight hill, walk slower than others, stop every 100 meters or after few minutes, severe breathlessness as grade $0,1,2,3$ and 4 respectively. Similarly, the secondary outcomes consisted of change of PAP at $12^{\text {th }}$ week and observation of adverse events and serious adverse events. The PAP was assessed by Echocardiography performed at different hospitals including Pakistan Institute of Medical Sciences; Shaheed Zulfiqar Ali Bhutto Medical University, Khyber Teaching Hospital; Peshawar and Multan health care. Apart from Bosentan, no other intervention was done other than oxygen repletion therapy during the study period.

\section{Data analysis}

The data analysis was performed by SPSS version 20.0. The quantitative data was presented as mean and standard deviation. Similarly the qualitative data was presented as frequency and percentages. Bar graph was used to express the qualitative data. Paired $\mathrm{t}$ - test and fisher exact test were used to assess the difference. The $\mathrm{p}$-value of $<0.05$ was taken as significant.

\section{Results}

5 patients did not complete the study visits and thus were excluded from the analysis. Out of total 35 patients selected for the analysis, the mean age was $59.31 \pm 9.23$ years, height was $162.29 \pm 8.67 \mathrm{~cm}$ and weight was $62.94 \pm 18.01 \mathrm{~kg}$ with male to female ratio of 2:1 (Table 1).

Table I Participants Profile

\begin{tabular}{|c|c|c|}
\hline Variables $(n=35)$ & & Mean \pm SD/Frequency (\%) \\
\hline Age (years) & & $59.31 \pm 9.23$ \\
\hline Height (cm) & & $162.29 \pm 8.67$ \\
\hline Weight (Kg) & & $62.94 \pm 18.01$ \\
\hline \multirow{2}{*}{ Gender } & Male & $22(62.8 \%)$ \\
\hline & Female & |3(37.2\%) \\
\hline \multirow{3}{*}{$\begin{array}{l}\text { History of } \\
\text { smoking }\end{array}$} & Never smokes & $10(28.6 \%)$ \\
\hline & Former smoker & 17(48.5\%) \\
\hline & Current Smoker & $8(22.9 \%)$ \\
\hline
\end{tabular}

For the observation of the patient before and after the treatment for 12 week duration, the most significant finding was improvement in shortness of breath during at rest $(\mathrm{p}=0.031)$ and physical activity $(p<0.001)$ which is the most common and aggravating symptom that aggravate the condition of patient. The improvements were also observed in performing daily $(\mathrm{p}=0.025)$ and social activities $(\mathrm{p}=0.046)$ (Table 2).

The MMRC dyspnea scale grades of the patients had significant difference before and after the treatment $(\mathrm{p}<0.01)$, and was found to be $0(0 \%), 3(8.6 \%), 10(28.6 \%), 14(40 \%)$, and $8(22.9 \%)$ patients in grade 1, 2, 3, 4 and 5 respectively before treatment. Similarly after treatment it was found in 1(2.9), 6(17.1\%), 13(37.1), 9(25.7\%) and $6(17.1 \%)$ patients respectively (Figure 1). 
Table 2 Clinical COPD questionnaire before and after treatment $(n=35)$

\begin{tabular}{|c|c|c|c|c|c|c|c|c|c|c|}
\hline \multicolumn{2}{|c|}{$\begin{array}{l}\text { On average, during the past } \\
\text { seven days, how often did } \\
\text { you feel: }\end{array}$} & & \multirow[t]{2}{*}{ Never } & \multirow{2}{*}{$\begin{array}{l}\text { Hardly } \\
\text { ever }\end{array}$} & \multirow{2}{*}{$\begin{array}{l}\text { A few } \\
\text { times } \\
6\end{array}$} & \multirow{2}{*}{$\begin{array}{l}\text { Several } \\
\text { times } \\
6\end{array}$} & \multirow{2}{*}{$\begin{array}{l}\text { Many } \\
\text { times } \\
\text { I I }\end{array}$} & \multirow{2}{*}{$\begin{array}{l}\text { A great } \\
\text { many times } \\
3\end{array}$} & \multirow{2}{*}{$\begin{array}{l}\text { Almost } \\
\text { all the } \\
\text { times } \\
2\end{array}$} & \multirow[t]{2}{*}{ P-value } \\
\hline \multirow{4}{*}{$\begin{array}{l}\text { I. Short breath at } \\
\text { rest? }\end{array}$} & \multirow{2}{*}{ Baseline } & $\mathrm{n}$ & & & & & & & & \\
\hline & & $\%$ & 5.7 & 14.3 & I7. I & I7.| & 31.4 & 8.6 & 5.7 & \multirow{3}{*}{0.031} \\
\hline & \multirow{2}{*}{$12^{\text {th }}$ week } & $\mathrm{n}$ & 5 & 5 & 12 & 5 & 4 & 3 & I & \\
\hline & & $\%$ & 14.3 & 14.3 & 34.3 & 14.3 & II. .4 & 8.6 & 2.9 & \\
\hline \multirow{4}{*}{$\begin{array}{l}\text { 2. Short of breath } \\
\text { doing physical } \\
\text { activities? }\end{array}$} & \multirow{2}{*}{ Baseline } & $\mathrm{n}$ & 0 & I & 3 & 6 & 12 & 7 & 6 & \multirow{4}{*}{$<0.001$} \\
\hline & & $\%$ & 0 & 2.9 & 8.6 & 17.1 & 34.3 & 20 & I7.I & \\
\hline & \multirow{2}{*}{$12^{\text {th }}$ week } & $\mathrm{n}$ & I & 2 & 7 & 16 & 3 & 4 & 2 & \\
\hline & & $\%$ & 2.9 & 5.7 & 20 & 45.7 & 8.6 & II. 4 & 5.7 & \\
\hline \multirow{4}{*}{$\begin{array}{l}\text { 3. Concerned } \\
\text { about getting } \\
\text { a cold or your } \\
\text { breathing getting } \\
\text { worse? }\end{array}$} & \multirow{2}{*}{ Baseline } & $\mathrm{n}$ & 5 & 3 & 4 & 6 & 10 & 4 & 3 & \multirow{4}{*}{0.108} \\
\hline & & $\%$ & 14.3 & 8.6 & II.4 & I7.I & 28.6 & II.4 & 8.6 & \\
\hline & \multirow{2}{*}{$12^{\text {th }}$ week } & $\mathrm{n}$ & 6 & 9 & 6 & 7 & 2 & 4 & 1 & \\
\hline & & $\%$ & 17.1 & 25.7 & 17.1 & 20 & 5.7 & II.4 & 2.9 & \\
\hline \multirow{4}{*}{$\begin{array}{l}\text { 4. Depressed } \\
\text { (down) because } \\
\text { of your breathing } \\
\text { problems? }\end{array}$} & \multirow{2}{*}{ Baseline } & $\mathrm{n}$ & 5 & 7 & 4 & 4 & 9 & 2 & 4 & \multirow{4}{*}{0.07} \\
\hline & & $\%$ & 14.3 & 20 & II.4 & II.4 & 25.7 & 5.7 & 11.4 & \\
\hline & \multirow{2}{*}{$12^{\text {th }}$ week } & $\mathrm{n}$ & 12 & 7 & 7 & 0 & 4 & I & 4 & \\
\hline & & $\%$ & 34.3 & 20 & 20 & 0 & II.4 & 2.9 & I I.4 & \\
\hline \multicolumn{11}{|c|}{$\begin{array}{l}\text { In general, during the } \\
24 \text { hours, how much of the } \\
\text { time }\end{array}$} \\
\hline & Baseline & $\mathrm{n}$ & 0 & I & 4 & 9 & 8 & 7 & 6 & \\
\hline & & $\%$ & 0 & 2.9 & II.4 & 25.7 & 22.9 & 20 & 17.1 & \\
\hline J. & $12^{\text {th }}$ week & $\mathrm{n}$ & 2 & 10 & 5 & 7 & 2 & 8 & I & 0.362 \\
\hline & & $\%$ & 5.7 & 28.6 & 14.3 & 20 & 5.7 & 22.9 & 2.9 & \\
\hline & Baseline & $\mathrm{n}$ & 1 & 2 & 10 & 3 & 7 & 6 & 6 & \\
\hline 6. Did you & & $\%$ & 2.9 & 5.7 & 28.6 & 8.6 & 20 & I7.I & 17.1 & 0.314 \\
\hline produce phlegm? & $12^{\text {th }}$ week & $n$ & 4 & 8 & 6 & 3 & 2 & 9 & 3 & 0.314 \\
\hline & & $\%$ & $1 \mathrm{I} .4$ & 22.9 & I7.1 & 8.6 & 5.7 & 25.7 & 8.6 & \\
\hline $\begin{array}{l}\text { On average, duri } \\
\text { past } 24 \text { hours, ho } \\
\text { were you in thes } \\
\text { because of your } \\
\text { problems }\end{array}$ & $\begin{array}{l}\text { limited } \\
\text { activities } \\
\text { eathing }\end{array}$ & & $\begin{array}{l}\text { Not } \\
\text { limited } \\
\text { at all }\end{array}$ & $\begin{array}{l}\text { Very } \\
\text { slightly } \\
\text { limited }\end{array}$ & $\begin{array}{l}\text { Slightly } \\
\text { limited }\end{array}$ & $\begin{array}{l}\text { Moderately } \\
\text { limited }\end{array}$ & $\begin{array}{l}\text { Very } \\
\text { limited }\end{array}$ & $\begin{array}{l}\text { Extremely } \\
\text { limited }\end{array}$ & $\begin{array}{l}\text { Totally } \\
\text { limited }\end{array}$ & P-value \\
\hline & & $\mathrm{n}$ & 0 & 0 & I & 4 & 12 & 3 & 15 & \\
\hline physical activities & B & $\%$ & 0 & 0 & 2.9 & II.4 & 34.3 & 8.6 & 42.9 & \\
\hline $\begin{array}{l}\text { (such as climbing } \\
\text { stairs, hurrying, }\end{array}$ & & $\mathrm{n}$ & 0 & 1 & 8 & 9 & 3 & 7 & 7 & 0.532 \\
\hline doing sport)? & $12^{\text {th }}$ week & $\%$ & 0 & 2.9 & 22.9 & 25.7 & 8.6 & 20 & 20 & \\
\hline & & $\mathrm{n}$ & 0 & 0 & 3 & 9 & 8 & 10 & 5 & \\
\hline $\begin{array}{l}\text { 8a. Moderate } \\
\text { physical activities }\end{array}$ & Baseline & $\%$ & 0 & 0 & 8.6 & 25.7 & 22.9 & 28.6 & 14.3 & \\
\hline (such as walking, & & $\mathrm{n}$ & I & 2 & 7 & 10 & 6 & 4 & 5 & 0.152 \\
\hline $\begin{array}{l}\text { housework, } \\
\text { carrying things)? }\end{array}$ & $12^{\text {th }}$ week & $\%$ & 2.9 & 5.7 & 20 & 28.6 & 17.1 & | I.4 & 14.3 & \\
\hline
\end{tabular}


Table Continued

\begin{tabular}{|c|c|c|c|c|c|c|c|c|c|c|}
\hline \multicolumn{3}{|c|}{$\begin{array}{l}\text { On average, during the past } \\
\text { seven days, how often did } \\
\text { you feel: }\end{array}$} & \multirow{2}{*}{$\begin{array}{l}\text { Never } \\
3\end{array}$} & \multirow{2}{*}{$\begin{array}{l}\text { Hardly } \\
\text { ever }\end{array}$} & \multirow{2}{*}{$\begin{array}{l}\text { A few } \\
\text { times } \\
9\end{array}$} & \multirow{2}{*}{$\begin{array}{l}\text { Several } \\
\text { times }\end{array}$} & \multirow{2}{*}{$\begin{array}{l}\text { Many } \\
\text { times } \\
6\end{array}$} & \multirow{2}{*}{$\begin{array}{l}\text { A great } \\
\text { many times } \\
5\end{array}$} & \multirow{2}{*}{$\begin{array}{l}\text { Almost } \\
\text { all the } \\
\text { times } \\
3\end{array}$} & \multirow{2}{*}{ P-value } \\
\hline \multirow{4}{*}{$\begin{array}{l}\text { 8b.Daily activities } \\
\text { at home (such as } \\
\text { dressing, washing } \\
\text { yourself)? }\end{array}$} & \multirow{2}{*}{ Baseline } & $\mathrm{n}$ & & & & & & & & \\
\hline & & $\%$ & 8.6 & 2.9 & 25.7 & 22.9 & 17.1 & 14.3 & 8.6 & \multirow{3}{*}{0.025} \\
\hline & \multirow{2}{*}{$12^{\text {th }}$ week } & $\mathrm{n}$ & 8 & 6 & 8 & 5 & 3 & 3 & 2 & \\
\hline & & $\%$ & 22.9 & 17.1 & 22.9 & 14.3 & 8.6 & 8.6 & 5.7 & \\
\hline \multirow{4}{*}{$\begin{array}{l}\text { 8c.Social activities } \\
\text { (such as talking, } \\
\text { being with } \\
\text { children, visiting } \\
\text { friends/relatives? }\end{array}$} & \multirow{2}{*}{ Baseline } & $\mathrm{n}$ & 4 & 6 & 8 & 4 & 3 & 5 & 5 & \multirow{4}{*}{0.046} \\
\hline & & $\%$ & 11.4 & 17.1 & 22.9 & II.4 & 8.6 & 14.3 & 14.3 & \\
\hline & \multirow[t]{2}{*}{$12^{\text {th }}$ week } & $\mathrm{n}$ & 12 & 15 & 2 & 0 & 1 & 4 & $\mathrm{I}$ & \\
\hline & & $\%$ & 34.3 & 42.6 & 5.7 & 0 & 2.9 & II.4 & 2.9 & \\
\hline
\end{tabular}

The mean pulmonary arterial pressure was performed in 28 patients out of the total of 35 patients who strictly fulfilled the inclusion criteria. It was $52.26 \pm 11.7 \mathrm{mmHg}$ before treatment and after treatment it was $44.56 \pm 11.52$ with a significant difference (p value $=0.004$ ). The six minute walk test was performed in 15 patients. The distance covered by the patient was increased after the therapy.
It was $164 \pm 94.79$ meters before therapy and $223.93 \pm 138.24$ meters after treatment with a significant difference ( $\mathrm{p}$ value $=0.01$ ) (Table 3 ). There were no reports of serious adverse events during the course of the study. However two patients reported side effects of dyspnea and oral candidiasis during the study.

Table 3 Comparison of pulmonary arterial pressure and six minute walk test before and after treatment

\begin{tabular}{|c|c|c|c|c|c|c|c|}
\hline Variables & & Range & Minimum & Maximum & Mean & STD & P-value \\
\hline \multirow{2}{*}{$\begin{array}{l}\text { Pulmonary arterial pressure } \\
(\mathrm{mmHg})(\mathrm{n}=28)\end{array}$} & Baseline & 40 & 25 & 65 & 52.26 & 11.7 & \multirow{2}{*}{0.004} \\
\hline & $12^{\text {th }}$ week & 45 & 20 & 65 & 44.56 & 11.52 & \\
\hline \multirow{2}{*}{6 min walk test (meters) $(n=15)$} & Baseline & 269 & 46 & 315 & 164.4 & 94.79 & \multirow{2}{*}{0.01} \\
\hline & $12^{\text {th }}$ week & 397 & 53 & 450 & 223.93 & 138.24 & \\
\hline
\end{tabular}

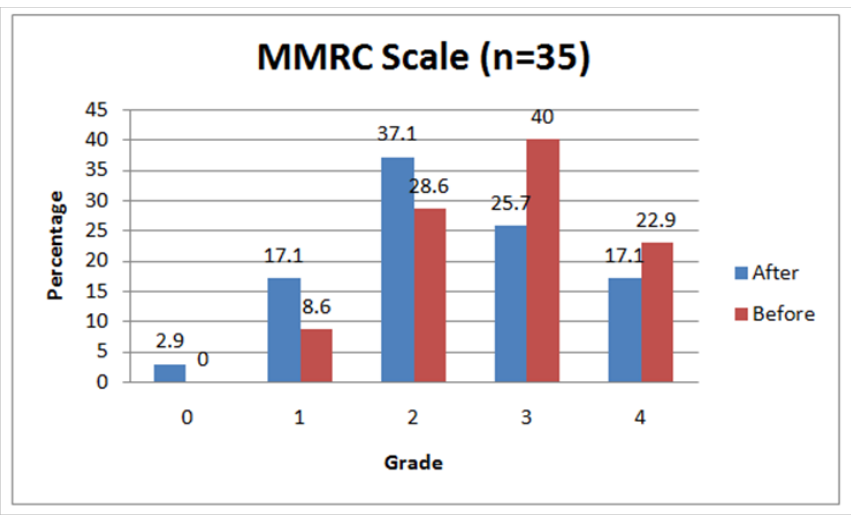

Figure I MMRC dyspnea Scale before and after the therapy.

\section{Discussion}

The study findings revealed that the breathlessness of the study participants as defined by the MMRC Dyspnea Scale was significantly improved after administration of the Bosentan. Moreover, the study results also showed that the mean pulmonary arterial pressure was significantly reduced whereas the mean distance on 6 minutes' walk test was significantly increased after administration of Bosentan. The study findings revealing the effectiveness of Bosentan in treating pulmonary hypertension, breathing difficulties and physical inabilities in patients of COPD is well in line with published literature. ${ }^{21-35}$

Galie $\mathrm{N}$ et al. ${ }^{14}$ reported mean pulmonary vascular resistance to be $83.2 \%$ of the standard level in patients treated with bosentan and $107.5 \%$ of the standard value in the placebo group (therapy effective $-22.6 \%, 95 \%$ CI -33.5 to $-10.0 ; \mathrm{p}<0.0001)$ following 6 months of treatment. ${ }^{21}$ Likewise, Sitbon $\mathrm{O}$ et al. ${ }^{22}$ reported that patients who have started Bosentan therapy enhanced their walking interval by $45 \pm 13 \mathrm{~m}$ after 6 months of treatment whereas prolong treatment with Bosentan for more than 1 year was associated with better hemodynamic parameters and modified NYHA functional class. ${ }^{22}$ Ulrich $\mathrm{S}$ et al. ${ }^{23}$ also reported that following six months of therapy with bosentan, the pulmonary vascular resistance reduced from 852 to 657 dynes $\mathrm{s} / \mathrm{cm}^{5}(\mathrm{p}=0.02)$, standard of living got better from a mean total score of 48 to $35(\mathrm{p}=0.003)$ and the 6 minutes' walk distance enhanced from 389 to 443 meters $(\mathrm{p}=0.005) .{ }^{23}$ Similarly, Valerio $\mathrm{G}$ et al. ${ }^{1}$ reported 18 months of Bosentan treatment to result in a significant improvement of pulmonary hypertension from $37+5$ to $31+6 \mathrm{mmHg}$ $(\mathrm{p}=0.002)$, pulmonary vascular resistance from $442+192$ to $392+180$ dynes $\mathrm{s} / \mathrm{cm}^{5}(\mathrm{p}=0.0115)$ and 6 minutes' walk distance from $256+118$ to $321+122$ meters $(\mathrm{p}=0.0027) .{ }^{1}$ Channick $\mathrm{RN}$ et al. ${ }^{9}$ also found that in patients treated with Bosentan, the walking interval in $6 \mathrm{~min}$ enhanced by $70 \mathrm{~m}$ at 12 weeks in contrast with standard level, however it got 
worst by $6 \mathrm{~m}$ in those on placebo $(\mathrm{p}=0 \cdot 021)$, pulmonary vascular resistance reduced by 223 dynes $\mathrm{s} / \mathrm{cm}^{5}$ with Bosentan and by 191 dynes $\mathrm{s} / \mathrm{cm}^{2}$ with placebo $(\mathrm{p}=0 \cdot 0002)$ whereas the patients who were given Bosentan had a decrease in Borg dyspnea index and a better WHO functional class as well. ${ }^{9}$ Similarly, Jais X et al. ${ }^{24}$ reported a statistically important effects of treatment with Bosentan over placebo on pulmonary vascular resistance $(\mathrm{p}<0.0001) .{ }^{24}$ Williamson DJ et al..$^{25}$ also reported Bosentan infusion to cause a dose-dependent fall in total pulmonary resistance $(\mathrm{p}=0.01)$ and mean pulmonary artery pressure $(\mathrm{p}>0.05) .{ }^{25}$ Likewise, Rubin LJ et al. ${ }^{26}$ reported at week 16 of treatment, patients on Bosentan had an improvement in six-minute walking interval; the mean difference between the placebo group and the combined Bosentan groups was $44 \mathrm{~m}(\mathrm{p}<0.001)$ whereas Bosentan also enhanced the Borg dyspnea index ( $p=0.42$ for $125 \mathrm{mg}$ dose and $\mathrm{p}=0.012$ for $250 \mathrm{mg}$ dose) and WHO functional class. ${ }^{26}$ Similarly, Hoeper MM et al. ${ }^{27}$ reported that following 3 months of therapy with Bosentan, pulmonary vascular resistance reduced from $914 \pm 329$ to $611 \pm 220$ dynes $\mathrm{s} / \mathrm{cm}^{5}(\mathrm{p}<0.001)$ whereas the 6 -min walk distance increased from $340 \pm 102$ to $413 \pm 130$ meters $(p=0.009) .{ }^{27}$ Hughes RJ et al. ${ }^{28}$ also found that after 1 year of Bosentan therapy, patients showed sustained improvements in 6-min walk test $(49 \pm 8$ $\mathrm{m}, \mathrm{p}<0.001)$, functional classification and total pulmonary resistance $\left(-139 \pm 42\right.$ dynes $\left.\mathrm{s} / \mathrm{cm}^{5}, \mathrm{p}=0.003\right) .{ }^{28}$ Likewise, Provencher $\mathrm{S}$ et $\mathrm{al} .{ }^{29}$ reported that after 4 and 12 months of Bosentan treatment, notable enhancement in exercise capacity and hemodynamics were witnessed which continued up to 1 year. ${ }^{29}$

The evidence cited above consistently shows that Bosentan has been repeatedly proven to be an effective treatment for COPD associated pulmonary manifestations, strongly supporting the findings of this study with the reduction of pulmonary arterial pressure from $52.26 \mathrm{~mm} \mathrm{Hg}$ to $44.56 \mathrm{~mm} \mathrm{Hg} \mathrm{(}=0.004)$ and improvement in the MMRC and dyspnea scale.

In addition to Bosentan monotherapy as in this study, it has also shown its effectiveness in the treatment of pulmonary hypertension when used in combination with prostaglandins. Hoeper MM et al., ${ }^{30}$ found that giving Bosentan for 3 months in addition to prostanoids resulted in the walking interval in the 6-min walk test increasing by $58 \pm 43 \mathrm{~m} .{ }^{30}$ Humbert $\mathrm{M}$ et al. ${ }^{31}$ also reported that hemodynamics, exercise capacity and functional class got better after16 weeks of Bosentan combination therapy with epo-prostenol. ${ }^{31}$

Similar to its effectiveness intreating pulmonary hypertension in adults, Bosentan has been shown to have beneficial effects in children as well. Rosenzweig EB et al..$^{32}$ found that treatment with Bosentan in children having pulmonary arterial hypertension resulted in reduced mean pulmonary artery pressure $(\mathrm{p}=0.005)$ and pulmonary vascular resistance $(\mathrm{p}=0.01){ }^{32}$ Barst $\mathrm{RJ}$ et al. ${ }^{33}$ also reported that following 12 weeks of treating children with pulmonary arterial hypertension, the mean difference from baseline in mean pulmonary artery pressure was $-8.0 \mathrm{~mm} \mathrm{Hg}(95 \%$ confidence interval, -12.2 to $-3.7 \mathrm{~mm} \mathrm{Hg})$, and that in pulmonary vascular resistance index was -300 dynes $\mathrm{s} / \mathrm{cm}^{5}(95 \%$ confidence interval, -576 to -24 dynes $\mathrm{s} / \mathrm{cm}^{5}{ }^{53}$

Though not one of the outcomes measures in this study and apart from its beneficial impact on pulmonary hypertension, pulmonary vascular resistance, breathing problems and physical inabilities discussed above, Bosentan treatment, either as mono or combination therapy, has also been reported to result in increased survival among patients having primary pulmonary hypertension as measured by
Kaplan-Meier survival estimates. ${ }^{29,34,35}$ The assistances of this study are that our suitable collection methodology and selection for this rare disease has qualified that we have appraised the accounts of extensive range patients of pulmonary hypertension. However, the study might not be immune from observer and recall bias. Reflecting the outcomes of patients after the treatment with Bosentan and to what range they are dependable with other treatment options for pulmonary hypertension and accounting the concomitant medicine used by the patients would be illuminating and valuable to homogenize the misconceptions about the treatment of the disease.

\section{Conclusion}

Even though it was an uncontrolled prospective study, Bosentan appeared to be effective in the treatment of dyspnea, limitation in physical activities, pulmonary hypertension and inability to walk due to shortness of breath in patients of chronic obstructive pulmonary disease suffering from pulmonary hypertension. Keeping the limitation of this study in mind, further studies focusing on the effectiveness of Bosentan in treating other manifestations of pulmonary hypertension in such patients are recommended to add weight to the findings of this study.

\section{Acknowledgements}

The declaration of all the patients for the study was documented by the authors. All authors acquire full responsibility for the material of the article. All authors communicated final approval of the description to be written. All authors are accountable to be answerable for all characteristic of the work and provide assurance that certify that the uncertainty linked to the precision of any element of the work are appropriately identified and corrected. NM is employee of Hilton Pharma, was engaged in the conceptualization, study design, data management proofreading $\&$ finalization.

\section{Conflict of interest}

Dr. Adnan Anwar, the Research Consultant was involved in drafting and finalization of document. There is no other conflict of interest.

\section{References}

1. Valerio G, Bracciale P, Grazia D'Agostino A. Effect of Bosentan upon pulmonary hypertension in chronic obstructive pulmonary disease. Therapeutic advances in respiratory disease. 2009;3(1):15-21.

2. Barbera JA, Blanco I. Pulmonary Hypertension in Patients with Chronic Obstructive Pulmonary Disease, Advances in Pathophysiology and Management. Drugs. 2009;69(9):1153-1171.

3. Fisher MR, Criner GJ, Fishman AP, et al. Estimating pulmonary artery pressures by echocardiography in patients with emphysema. Eur Respir J. 2007;30(5):914-921.

4. Thabut G, Dauriat G, Stern JB, et al. Pulmonary Hemodynamics in Advanced COPD Candidates for Lung Volume Reduction Surgery or Lung Transplantation. Chest. 2005;127(5):1531-1536.

5. Chaouat A, Naeije R, Weitzenblum E. Pulmonary hypertension in COPD. Eur Respir J. 2008;32(5):1371-1385.

6. Chaouat A, Bugnet AS, Kadaoui N, et al. Severe Pulmonary Hypertension and Chronic Obstructive Pulmonary Disease. Am J Respir Crit Care Med. 2005;172(2):189-194. 
7. Oswald-Mammoser M, Weitzenblum E, Quoix E, et al. Prognostic Factors in COPD Patients Receiving Long-term Oxygen Therapy: Importance of Pulmonary Artery Pressure. Chest. 1995;107(5):1193-1198.

8. Barbera JA, Peinado VI, Santos S. Pulmonary hypertension in chronic obstructive pulmonary disease. Eur Respir J. 2003;21:1892-1905.

9. Channick RN, Simponneau G, Ditbon O, et al. Effects of the dual endothelin-receptor antagonist Bosentan in patients with pulmonary hypertension: a randomised placebo-controlled study. Lancet. 2001;358:1119-1123.

10. Bishop JM. Cardiovascular complication of chronic bronchitis and emphysema. Me Chin North Am. 1973;57(3):771-780.

11. Chemla D, Castelain V, Henrie P, et al. Haemodynamic evaluation of pulmonary hypertension, Eur Resp J. 2002;20(5):1314-1331.

12. Scharf SM, Iqbal M, Keller C, et al. Hemodynamic Characterization of Patients with Severe Emphysema. Am J Respir Crit Care Med. 2002;166(3):314-322.

13. Hale K, Niewoehner D, Cosio MG. Morphologic Changes in the Muscular Pulmonary Arteries: Relationship to Cigarette Smoking, Airway Disease, and Emphysema. American Review of Respiratory Disease. 1980;122(2):273-278.

14. Galie N, Hoeper MM, Humbert M, et al. The task force for the diagnosis and treatment of pulmonary hypertension of the European Society of Cardiology (ESC) and the European Respiratory Society (ERS) endorsed by the international Society of Heart and Lung Transplantation (ISHLT) Guidelines for the diagnosis and treatment of pulmonary hypertension. Eur Respir J. 2009;34(6):1219-1263.

15. Hoeper MM, Andreas S, Bastian A, et al. Pulmonary Hypertension due to chronic lung disease: Updated Recommendations of the Cologne Consensus Conference 2011. International Journal of Cardiology. 2011;154 Suppl 1:S45-53.

16. Chen SJ, Chen YF, Meng QC, et al. Endothelin-receptor antagonis Bosentan prevents and reverses hypoxic pulmonary hypertension in rats. J Appl Physiol. 1995;79(6):2122-2131.

17. Roig Figueroa V, HerreroPerzez A, Abad Lecha E, et al. Bosentan in pulmonary hypertension associated with hypoxaemic lung diseases. Current Medical Research and Opinion. 2007;23 Suppl 2:S49-53.

18. Voelkel NF. Mechanisms of hypoxic pulmonary vasoconstriction. Am Rev Respir Dis. 1986;133(6):1186-1195.

19. Halank M, Rubens C, Orezechowki HD. Big endothelin 1 plasma levels and hemodynamics in patients with pulmonary hypertension of different origin. Am J Critic Care Med. 1999;159(3):159-165.

20. Valerio G, Mancini NM, Bracciale P. Endotelina 1 nel circolo polmonare in corso di bronchite cronica ostruttiva. Effet to dellaossigenoterapia e dell'ossido di azoto, Rassegna di Pat App Resp. 2002;17:35-40.

21. Galiè N, Rubin LJ, Hoeper MM, et al. Treatment of patients with mildly symptomatic pulmonary arterial hypertension with Bosentan (EARLY study): a double-blind, randomised controlled trial. The Lancet. 2008;371(9630):2093-2100.
22. Sitbon O, Badesch DB, Channick RN, et al. Effects of the dual endothelin receptor antagonist Bosentan in patients with pulmonary arterial hypertension: a 1-year follow-up study. CHEST Journal. 2003;124(1):247-254

23. Ulrich S, Speich R, Domenighetti G, et al. Bosentan therapy for chronic thromboembolic pulmonary hypertension. A national open label study assessing the effect of Bosentan on haemodynamics, exercise capacity, quality of life, safety and tolerability in patients with chronic thromboembolic pulmonary hypertension (BOCTEPH-Study). Swiss medical weekly. 2007;137(41-42):573-580.

24. Jaïs X, D’Armini AM, Jansa P, et al. Bosentan for treatment of inoperable chronic thromboembolic pulmonary hypertension: BENEFiT (Bosentan Effects in iNopErable Forms of chronIc Thromboembolic pulmonary hypertension), a randomized, placebo-controlled trial. Journal of the American College of Cardiology. 2008;52(25):2127-2134.

25. Williamson DJ, Wallman LL, Jones R, et al. Hemodynamic effects of Bosentan, an endothelin receptor antagonist, in patients with pulmonary hypertension. Circulation. 2000;102(4):411-418.

26. Rubin LJ, Badesch DB, Barst RJ, et al. Bosentan therapy for pulmonary arterial hypertension. New England Journal of Medicine. 2002;346(12):896-903.

27. Hoeper MM, Kramm T, Wilkens H, et al. Bosentan therapy for inoperable chronic thromboembolic pulmonary hypertension. CHEST Journal. 2005;128(4):2363-2367.

28. Hughes RJ, Jais X, Bonderman D, et al. The efficacy of Bosentan in inoperable chronic thromboembolic pulmonary hypertension: a 1-year follow-up study. European Respiratory Journal. 2006;28(1):138-143.

29. Provencher S, Sitbon O, Humbert M, et al. Long-term outcome with first-line Bosentan therapy in idiopathic pulmonary arterial hypertension. European heart journal. 2006;27(5):589-595.

30. Hoeper MM, Taha N, Bekjarova A, et al. Bosentan treatment in patients with primary pulmonary hypertension receiving non parenteral prostanoids. European Respiratory Journal. 2003;22(2):330-334.

31. Humbert M, Barst RJ, Robbins IM, et al. Combination of Bosentan with epoprostenol in pulmonary arterial hypertension: BREATHE-2. European Respiratory Journal. 2004;24(3):353-359.

32. Rosenzweig EB, Ivy DD, Widlitz A, et al. Effects of long-term Bosentan in children with pulmonary arterial hypertension. Journal of the American College of Cardiology. 2005;46(4):697-704.

33. Barst RJ, Ivy D, Dingemanse J, et al. Pharmacokinetics, safety, and efficacy of Bosentan in pediatric patients with pulmonary arterial hypertension. Clinical Pharmacology \& Therapeutics. 2003;73(4):372-382.

34. Sitbon O, McLaughlin VV, Badesch DB, et al. Survival in patients with class III idiopathic pulmonary arterial hypertension treated with first line oral Bosentan compared with an historical cohort of patients started on intravenous epoprostenol. Thorax. 2005;60(12):1025-1030.

35. McLaughlin VV, Sitbon O, Badesch DB, et al. Survival with first-line Bosentan in patients with primary pulmonary hypertension. European Respiratory Journal. 2005;25(2):244-249. 